\title{
Opinion and Special Articles: Challenges and opportunities in defining career identity in academic neurology
}

David J. Lin, MD, Merit E. Cudkowicz, MD, MSc, and Tracey A. Cho, MD

Neurology ${ }^{\circledR}$ 2018;91:670-672. doi:10.1212/WNL.0000000000006284
Correspondence

Dr. Lin

dlin7@mgh.harvard.edu

There has never been a more exciting time to become a neurologist. As we emerge from training in clinical neurology after 4 or more years of residency and fellowship, many of us are faced with the core challenge of how to define and develop our career identity. That is, how do we continue to take great care of our patients, and now also advance our careers and make contributions to a dynamic field? Here, we focus on developing career identity within academic neurology, noting that careers in private practice neurology and other settings have unique sets of challenges, rewards, and opportunities.

In academic neurology, as in academic medicine, the 3 traditional cornerstones are patient care, education, and research. The canonical academic identities are the physician-scientist, clinician-educator, and "triple threat" (clinician, researcher, and educator). The process of developing career identity in academic neurology has always been challenging, often occurring at a critical period of other life milestones, such as purchasing homes or expanding families. Successfully establishing oneself and finding meaning in one's work is critical for career satisfaction and preventing burnout. ${ }^{1}$ Today, given the changing landscape of neurology, the process of developing career identity has unique opportunities and challenges. We highlight these issues and discuss potential solutions that can be instituted at the departmental, organizational, and national levels.

Perhaps the most well-paved career track for academic neurologists is that of the physicianscientist. Milestones for career advancement for physician-scientists are relatively clear-grant funding enables protected time, allowing for productivity in the form of publications, which in turn facilitates local, national, and international recognition. While the milestones are relatively clear, emerging as an independent physician-scientist seems more daunting than ever. Several articles in the last decade have highlighted the obstacles facing physician-scientists, including mounting medical school debt, the long years of training required, the growing complexities of both clinical and research documentation, and historically flat to downtrending NIH paylines. ${ }^{2,3}$ More can be done by academic departments and organizations to help facilitate dual clinician-research careers. First, during clinical training, despite often being in close geographic proximity to basic and clinical scientists, it is not immediately obvious how to become meaningfully involved in a scientific program. On the other side of the coin, many neuroscientists are hungry for clinical perspectives to inform their ongoing research. Thus, more local initiatives such as speaker series, joint conferences, and social events to encourage dialogue about synergistic goals and complementary skill sets between scientists and clinicians, starting during early career phases, would be helpful.

Second, mentored career transition awards for clinician-scientists such as the NIH K award (K08 or K23) are more difficult to obtain, ${ }^{4}$ certainly as compared to the early 2000 s, which saw a doubling in the NIH budget between 1998 and 2003. ${ }^{5,6}$ Given the stiff competition for limited funding, successful $\mathrm{K}$ awards now seemingly require at the minimum preliminary data equivalent to or resulting in a paper, a dedicated mentor and supportive scientific environment, and clear milestones to scientific independence. To this end, pre-K-award 
programs such as the NIH R25 grant and AAN Career Development Awards have been successful in helping to provide protected time to acquire some skills and gather preliminary data. Additional or expanded funding along these lines provided by departments and organizations will be helpful to encourage trainees forming an identity in research. Early seed funding for novel ideas and method development that represent a departure from those of established mentors will help support innovation and new perspectives from emerging clinician-scientists.

The comprehensive clinical translation process, from identification of a question in clinical neurology to hypothesisdriven scientific experiments at the bench to drug and device development and clinical trials in humans, requires expertise spanning innumerable aspects of basic, clinical, and translational science. Institutions and organizations should recognize the current gaps in the clinical translation process and strategically focus funding, starting at the level of trainees, to encourage all types of investigation. ${ }^{7,8}$ More support for young investigators to gain specific expertise in drug and device development as well as clinical trials should be provided as these have not been traditional focus areas for career development grants. This also should include the recognition that industry (e.g., biotechnology, pharmaceutical, and medical device companies) can uniquely contribute to the scientific training of young investigators (i.e., via joint academic-industry fellowship programs). As academic and industry interests align, it will also be beneficial for young clinical investigators to learn to manage potential conflicts of interest.

In contrast to the relatively well-worn path towards becoming a physician-scientist, there is no clear track for aspiring clinician-educators. This is unfortunate because as the diagnostic and therapeutic complexity of clinical neurology continues to increase, the value of effective educators in clinical neurology has never been more apparent. Those interested in medical education in neurology usually dedicate additional time during training to teaching medical students and resident peers. Mentors who have been successful in the area of medical education (i.e., residency program directors or medical student clerkship directors) can provide valuable advice. But after training ends, there are no clear or common mechanisms to help residents and fellows develop medical education careers. At many institutions, there is no dedicated academic advancement track for clinician-educators. On this note, and as a first step, academic departments need to

Table Suggested local and national solutions to promote career development for neurology-trained clinician-scientists, clinician-educators, and academic neurologists

\begin{tabular}{|c|c|c|c|}
\hline & Academic neurologists & Neurologist-scientists & Neurologist-educators \\
\hline \multirow[t]{2}{*}{ Local/departmental } & $\begin{array}{l}\text { Create initiatives during residency } \\
\text { such as certificate programs or } \\
\text { scholarly pursuits that provide } \\
\text { neurology trainees with additional } \\
\text { structure and mentorship around } \\
\text { specific focus and interest areas (i.e., } \\
\text { global health, diversity and inclusion, } \\
\text { quality and safety) }\end{array}$ & $\begin{array}{l}\text { Form initiatives encouraging dialogue } \\
\text { and synergy between scientists and } \\
\text { clinicians }\end{array}$ & $\begin{array}{l}\text { Provide courses or workshops with } \\
\text { specific curricula for developing } \\
\text { neurologic teaching skills }\end{array}$ \\
\hline & $\begin{array}{l}\text { Critically evaluate and learn from } \\
\text { programs and structures that help } \\
\text { support clinician-scientists and } \\
\text { clinical educators }\end{array}$ & $\begin{array}{l}\text { Provide seed funding to develop } \\
\text { novel ideas and methods }\end{array}$ & $\begin{array}{l}\text { Create Master Clinician programs } \\
\text { that bring together education- } \\
\text { oriented faculty and provide focused } \\
\text { bedside teaching to trainees }\end{array}$ \\
\hline
\end{tabular}

Support academic-industry partnerships geared toward development of young clinician-scientists (i.e., joint fellowship programs)

\begin{tabular}{|c|c|c|c|}
\hline \multirow[t]{3}{*}{ Organizational/national } & $\begin{array}{l}\text { Develop support structures for } \\
\text { nontraditional academic } \\
\text { neurologists; i.e., neurologists } \\
\text { focused on hospital medicine } \\
\text { (neurohospitalists), patient safety, or } \\
\text { global health, among others }\end{array}$ & $\begin{array}{l}\text { Provide additional early career } \\
\text { funding opportunities to allow } \\
\text { protected time for scientific } \\
\text { development and preliminary data } \\
\text { collection for trainees and early } \\
\text { faculty }\end{array}$ & $\begin{array}{l}\text { Provide grant funding geared } \\
\text { specifically for the development of } \\
\text { teaching skills in clinical neurology }\end{array}$ \\
\hline & & $\begin{array}{l}\text { Create formal programs for young } \\
\text { investigators to gain expertise in } \\
\text { clinical trials and drug and device } \\
\text { development }\end{array}$ & $\begin{array}{l}\text { Develop ACGME fellowship programs } \\
\text { in neurology clinical education }\end{array}$ \\
\hline & & & $\begin{array}{l}\text { Identify and reserve sources of } \\
\text { funding for dedicated teaching time } \\
\text { from clinical educators }\end{array}$ \\
\hline
\end{tabular}

Develop clear milestones for academic advancement of educationoriented faculty

Provide grant funding geared specifically for the development of funding opportunities to allow collection for trainees and early clinical trials and drug and device m clinical educators 
recognize the unique value that effective clinician-teachers bring to neurology and establish clear milestones for career advancement for education-focused faculty. Different from grants and papers in the research track, such milestones may include patient outcome metrics, teaching awards, or feedback by trainees and peers on teaching and mentorship.

One of the main challenges is funding for careers in neurology education. There are currently no funding mechanisms to support time dedicated to teaching. Here we draw a distinction between developing teaching skills in neurology vs medical education research. To preserve the art of clinical neurology, funding should be dedicated to developing the unique set of skills necessary for highly effective and engaging teaching of clinical neurology. This could come in the form of departmental or national courses and conferences with specific and objective curricula for developing neurologic teaching skills. Accreditation Council for Graduate Medical Education-accredited fellowship programs for neurology educators should be developed. Master Clinician programs within academic departments that bring together educationoriented faculty at all levels could provide (1) real-time patient-focused teaching and feedback on the neurologic history, examination, diagnosis, and management to trainees; (2) a community of faculty with distinct clinical experience and expertise; and (3) synergy and structure around clinical education.

It would be naive and perhaps wishful to think that funding in our current model of reimbursement would provide substantial protected time for young faculty to teach. To this end, creative sources of funding for education should be considered. Could Medicare recognize the unique talent of clinical educators by earmarking teaching funds for individuals or departments? Or could clinician-educators who have a track record of clinical excellence and expertise receive more in reimbursement for dedicating extra time to teaching trainees during a patient encounter?

We have thus far discussed the process of defining career identity for clinician-scientists and clinician-teachers, but what about new and emerging identity templates in academic neurology? For example, the growing volume, demand, and complexity of inpatient neurology services coupled with national pressure to reduce in-hospital length of stay has fueled the birth and growth of the neurohospitalists, who specialize in the high quality and efficient delivery of in-hospital care to neurology patients. ${ }^{9,10}$ How do neurohospitalists create academic identity as they negotiate their funding and time among clinical care, education, and research? Furthermore, patient safety and quality, neurology in the developing world (global health), and diversity and inclusion both in departments and in the field are all critical conversations in neurology today. We need to cultivate residents, fellows, and young faculty with mentorship, protected time, and clear milestones for career advancement in all of these areas. Initiatives during residency programs such as certificate programs, tracks, or scholarly pursuits that provide additional training, mentoring, and structure can help trainees explore different interests early on. We should evaluate the programs and structures that are working for clinician-scientists and what is starting to work in the area of clinical education for inspiration to help develop experts in neurology quality and safety, global health, and diversity and inclusion.

More can be done at the departmental and national levels to support the academic development of young neurologists. Aspiring clinician-scientists would benefit from additional early-career funding to develop novel ideas and methods as well as more formalized training in clinical trial methodology as well as drug and device development. Clinician-educators would benefit from specific programs focused on the development of clinical teaching skills, finding concrete ways to dedicate funds for time spent on teaching, and the development of clear milestones for academic institutional advancement. Ongoing evaluation of structures and programs for clinician-scientists and clinician-educators will inform the development of other identities in academic neurology (table). Such upfront investments by departments and national organizations will help prevent burnout, maximize career satisfaction, and usher in the next generation of leaders in neurology.

\section{Author contributions}

David Lin: manuscript concept, manuscript draft. Tracey Cho: manuscript concept, manuscript draft. Merit Cudkowicz: manuscript concept, manuscript revision.

\section{Acknowledgment}

The authors thank Martin A. Samuels for comments on this manuscript.

\section{Study funding}

No targeted funding reported.

\section{Disclosure}

The authors report no disclosures relevant to the manuscript. Go to Neurology.org/N for full disclosures.

\section{References}

1. Busis NA, Shanafelt TD, Keran CM, et al. Burnout, career satisfaction, and well-being among US neurologists in 2016. Neurology 2017;88:797-808.

2. Hauser SL, McArthur JC. Saving the clinician-scientist: report of the ANA long range planning committee. Ann Neurol 2006;60:278-285.

3. Carmichael ST. Opinion and Special Articles: A guide from fellowship to faculty: Nietzsche and the academic neurologist. Neurology 2012;79:e116-e119.

4. Banks D, Juliana Blome N, Liza Bundesen N, et al. National Institutes of Health Individual Mentored Career Development Awards Program Evaluation Working Group. Available at: researchtraining.nih.gov/sites/default/files/pdf/K_Awards Evaluation_FinalReport_20110901.pdf\#. Accessed May 27, 2018.

5. Larson RC, Ghaffarzadegan N, Diaz MG. Magnified effects of changes in NIH research funding levels. Serv Sci 2012;4:382-395.

6. Garrison $\mathrm{HH}$, Deschamps AM. NIH research funding and early career physician scientists: continuing challenges in the 21st century. FASEB J 2014;28:1049-1058.

7. Zerhouni EA. US biomedical research. JAMA 2005;294:1352.

8. Johnston SC, Hauser SL. Basic and clinical research: what is the most appropriate weighting in a public investment portfolio? Ann Neurol 2006;60:A9-A11.

9. Freeman WD, Josephson SA. The birth of neurohospitalists. Neurohospitalist 2011;1: 5-7.

10. Josephson SA, Engstrom JW, Wachter RM. Neurohospitalists: an emerging model for inpatient neurological care. Ann Neurol 2008;63:135-140. 


\title{
Neurology
}

\author{
Opinion and Special Articles: Challenges and opportunities in defining career identity \\ in academic neurology \\ David J. Lin, Merit E. Cudkowicz and Tracey A. Cho \\ Neurology 2018;91;670-672 \\ DOI 10.1212/WNL.0000000000006284
}

\section{This information is current as of October 1, 2018}

\begin{tabular}{|c|c|}
\hline $\begin{array}{l}\text { Updated Information \& } \\
\text { Services }\end{array}$ & $\begin{array}{l}\text { including high resolution figures, can be found at: } \\
\text { http://n.neurology.org/content/91/14/670.full }\end{array}$ \\
\hline References & $\begin{array}{l}\text { This article cites } 9 \text { articles, } 2 \text { of which you can access for free at: } \\
\text { http://n.neurology.org/content/91/14/670.full\#ref-list- } 1\end{array}$ \\
\hline Citations & $\begin{array}{l}\text { This article has been cited by } 2 \text { HighWire-hosted articles: } \\
\text { http://n.neurology.org/content/91/14/670.full\#\#otherarticles }\end{array}$ \\
\hline Subspecialty Collections & $\begin{array}{l}\text { This article, along with others on similar topics, appears in the } \\
\text { following collection(s): } \\
\text { All Education } \\
\text { http://n.neurology.org/cgi/collection/all_education } \\
\text { Methods of education } \\
\text { http://n.neurology.org/cgi/collection/methods_of_education }\end{array}$ \\
\hline Permissions \& Licensing & $\begin{array}{l}\text { Information about reproducing this article in parts (figures,tables) or in } \\
\text { its entirety can be found online at: } \\
\text { http://www.neurology.org/about/about_the_journal\#permissions }\end{array}$ \\
\hline Reprints & $\begin{array}{l}\text { Information about ordering reprints can be found online: } \\
\text { http://n.neurology.org/subscribers/advertise }\end{array}$ \\
\hline
\end{tabular}

Neurology ${ }^{\circledR}$ is the official journal of the American Academy of Neurology. Published continuously since 1951, it is now a weekly with 48 issues per year. Copyright (O 2018 American Academy of Neurology. All rights reserved. Print ISSN: 0028-3878. Online ISSN: 1526-632X.

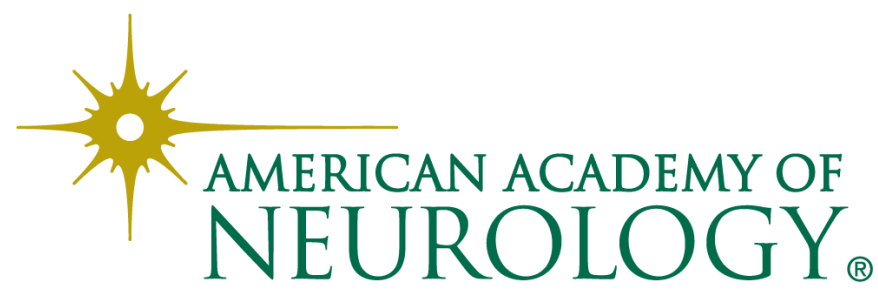

